IRA-International Journal of Management \& Social Sciences

ISSN 2455-2267; Vol.08, Issue 01 (July 2017)

Pg. no. 91-97

Institute of Research Advances

http://research-advances.org/index.php/RAJMSS

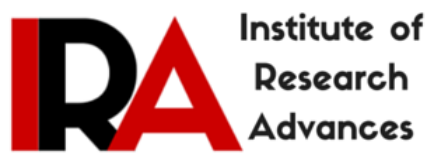

\title{
Financial Literacy of Financed Rural Development Projects and their Contribution to the Gross Domestic Product
}

\author{
Benias Mapepeta $(\mathrm{PhD})$ \\ Administrator/Lecturer, Zimbabwe Ezekiel Guti University (ZEGU) Masvingo Campus, \\ Zimbabwe. \\ Rejoice Mandizvidza \\ Lecturer, Accounting and Information Systems, Great Zimbabwe University (GZU), Zimbabwe.
}

Type of Review: Peer Reviewed.

DOI: http://dx.doi.org/10.21013/jmss.v8.n1.p10

How to cite this paper:
Mapepeta, B., \& Mandizvidza, R. (2017). Financial Literacy of Financed Rural Development Projects and
their Contribution to the Gross Domestic Product. IRA-International Journal of Management \& Social
Sciences (ISSN 2455-2267), 8(1), 91-97. doi:http://dx.doi.org/10.21013/jmss.v8.n1.p10

(C) Institute of Research Advances.

\section{(cc) EY-NC}

This work is licensed under a Creative Commons Attribution-Non Commercial 4.0 International License subject to proper citation to the publication source of the work.

Disclaimer: The scholarly papers as reviewed and published by the Institute of Research Advances (IRA) are the views and opinions of their respective authors and are not the views or opinions of the IRA. The IRA disclaims of any harm or loss caused due to the published content to any party.

Institute of Research Advances is an institutional publisher member of Publishers Inter Linking Association Inc. (PILA-CrossRef), USA. The institute is an institutional signatory to the Budapest Open Access Initiative, Hungary advocating the open access of scientific and scholarly knowledge. The Institute is a registered content provider under Open Access Initiative Protocol for Metadata Harvesting (OAI-PMH).

The journal is indexed \& included in WorldCat Discovery Service (USA), CrossRef Metadata Search (USA), WorldCat (USA), OCLC (USA), Open J-Gate (India), EZB (Germany) Scilit (Switzerland), Airiti (China), Bielefeld Academic Search Engine (BASE) of Bielefeld University, Germany, PKP Index of Simon Fraser University, Canada. 


\begin{abstract}
For rural development projects, prosperity hides in financial literacy. However, measurement of financial literacy hampers profitability evidenced through proper record keeping and accountability which has been a thorn in the flesh of the responsible ministries. This research seeks to investigate financial literacy and proper record keeping in rural development projects and how it could be used to measure contributions to the Gross Domestic Product. Thus, the major objective of this paper is to analyse financial record keeping and measurement of profitability in rural development projects in Zimbabwe. The literature review was centred on the empiric researches and publications from other scholarly researchers. The data that was collected was presented using frequency tables and graphs done using Microsoft Excel and Statistical Packages of Social Sciences (SPSS). The researchers found out that even though the rural development projects are viable entities, there are not records to measure their profitability. It was also found out that the there are other players taking advantage of non-record keeping capitalising on the profits of the rural development projects which makes them dwarf enterprises. The researchers concluded that if proper record keeping and financial literacy is to be implemented, measurement of profitability will be beneficial to both responsible authorities and policy makers. The researchers recommended that the stakeholders should work towards systemising record keeping and accounting systems that enables measurement of profitability amongst rural development projects.
\end{abstract}

Key words: Rural development projects, Sustainability.

\title{
1.0 Introduction
}

Zimbabwe is classified as one of the poorest nations in the world with the majority of the population living in rural areas where survival and sustenance has always been classified as vulnerable. Thus, financial literacy is a taboo that can actually help these people from vulnerability. Financial literacy which entails life financial management and risk reduction would be very useful in rural areas. That is the gist of this study to reveal financial literacy levels in rural Zimbabwe and how it is affecting figures of the GDP of the country.

\subsection{Background}

It is common knowledge that the rural poor are caught in the vicious cycle of poverty and vicious cycle of vulnerability. Micro Finance movements aims at achieving reduction or eradication of this condition and provides financial services like Savings, Credit, Insurance, Pension, Remittances but along with these services there is a need to help them to learn to "manage their finances" by helping them, build their knowledge and skill about Financial Management and to help them change their Financial behaviors (Olatunji, 2013).

In a related study of The Role of Agriculture (2014) project findings and country case study results call attention to a diverse set of indirect environmental, social and economic contributions of rural agriculture projects. The evidence suggests that these indirect contributions are not well understood, seldom analyzed in the context of development, and rarely reflected in national and rural development policy strategies (FAO, 2004).

However, financial literacy consists of three programmes which are awareness building programme for helping poor to change their attitude towards money or their financial behaviour e.g. Instead of living or thinking on day to day bases, make them to think about future and plan for future, that is, think about life cycle needs, stop making impulsive Financial decisions. e.g. Think before Borrowing. They should manage finances instead of just dealing with money. e.g. understand principle of fungibility of money ( Moore, Petty, Palich and Longernecker, 2008).

The other programme is financial knowledge building programme, which is knowledge about importance of saving regularly, small amounts and power of compounding, use of insurance to minimize risk, difference between consumption and investment, difference between avoidable and unavoidable expenses, different methods of interest calculation and Fungibility concept

The third and final programme is the financial skill building programmes which are, building skill of preparing Budget and building skill of preparing financial plan or interest calculation. 
With the current legal and regulatory framework in Zimbabwe and with the increase in number of the lending institutions, the problem of funding for this sector has decreased (Economic Survey 2006). The problem that might require emphases in research would be the management of the rural development projects. Efficient managing of these enterprises involves accounting a practice which is highly dependent on the record keeping of the business transactions (Maseko and Manyani, 2011).

A sound accounting and internal control system in any business irrespective of its scale is crucial. Audits of small scale enterprises have proven to be worrisome for professional accountants because of the inadequacy of the internal controls. Except for statutory demands, small and medium enterprises hardly give serious thoughts to the process of sound accounting yet the adequacy and ineffectiveness of accounting processes have been responsible for the ultimate collapse of a host of them (Mukaila and Adeyami, 2011).

A business organization could measure its performance using the financial and non-financial measures. The financial measures include profit before tax and turnover while the non-financial measures focus on issues pertaining to customers' satisfaction and customers' referral rates, delivery time, waiting time and employees' turnover however for these rural projects neither exists and therefore performance is not measured.

There is a general understanding of basic financial institutions and financial concepts such as credit and saving. There is, furthermore, a general awareness of the risks associated with credit taking. This is none existent with rural projects.

\subsection{Objectives of this study}

The objectives of this study are:

- $\quad$ to investigate financial literacy and proper record keeping in rural development projects and

- $\quad$ to explore how it could be used to measure contributions to the Gross Domestic Product

\subsection{Methods/Methodology}

Due to the characteristic of this study, both quantitative and qualitative research methods were found suitable. Thus, a descriptive survey was used as a research design to support the quantitative and qualitative research methods.

\subsection{Population}

The universal population of this study was all the rural projects that are scattered in rural Zimbabwe. However, the target population from which a sample was selected was the rural projects in Bikita District, Masvingo.

\subsection{Sample and Sampling Procedure}

The total exact number of all the small rural projects in Bikita could not be reached and therefore stratum were establish which classify financed rural projects into manufacturing, Agri-Dealers, Service Providers, Transport and General Dealers. From these stratum, simple random sampling was used to select participants from these populates. The long process resulted in a sample of 50 participants whereby a sample of 10 participants was chosen from each strata.

\subsection{Research Instruments}

\subsubsection{Questionnaires}

Questionnaires were found to be appropriate in soliciting information from the manufacturing and services strata because they are the participants with ample time to look at a questionnaire and answer the questions.

\subsubsection{Interviews}

The rural projects which most of them are informal traders in flea markets and agriculturists was a larger group. They do not have much time to sit and understand a questionnaire and most of them do not have 
time to fill forms like questionnaires so, it was easy to interview them while they are doing their duties. So, the transport, Agri-dealers and the General Dealers were found appropriate to be interviewed.

\subsubsection{Data Presentation Procedures}

The simple Microsoft Excel Computer package was used to tabulate frequency tables and graphs used to present the data that was collected from the field.

\subsection{Results/Findings}

\section{Application of financial literacy and record keeping by rural projects}

\section{Question 1: Financial literacy and proper record keeping in rural development projects}

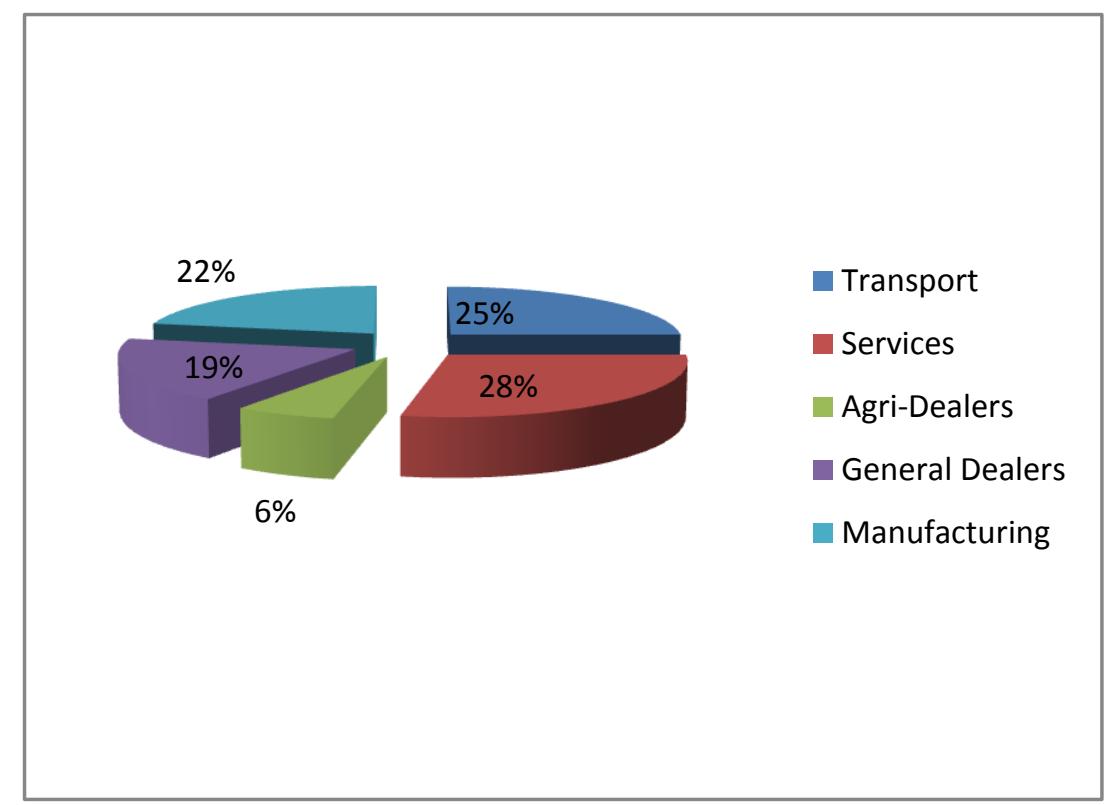

\section{Figure 4.1 Awareness of financial literacy and record keeping}

Fig 4.1 above shows that $28 \%$ of the participants were the Service providers who indicated that they were aware of financial record keeping but do not keep any records and hence were financially illiterate. Because of the registration requirements and tax compliance from Zimbabwe Revenue Authority (ZIMRA) they had no option but to keep records yet they do not keep any. This was echoed by the Transport Sector (25\%), who are under spotlight from both the Revenues Authorities and the Police and hence they have to keep records yet still they do not. The Manufacturing (22\%) sector expressed the same sentiments even though they are more informal. The General dealers (19\%) expressed the same views. However, the Agri-Dealers (6\%) showed no or little knowledge of record keeping and hence the demonstrated that they do not keep any records at all. 


\section{Question 2: How to measure contributions to the Gross Domestic Product}

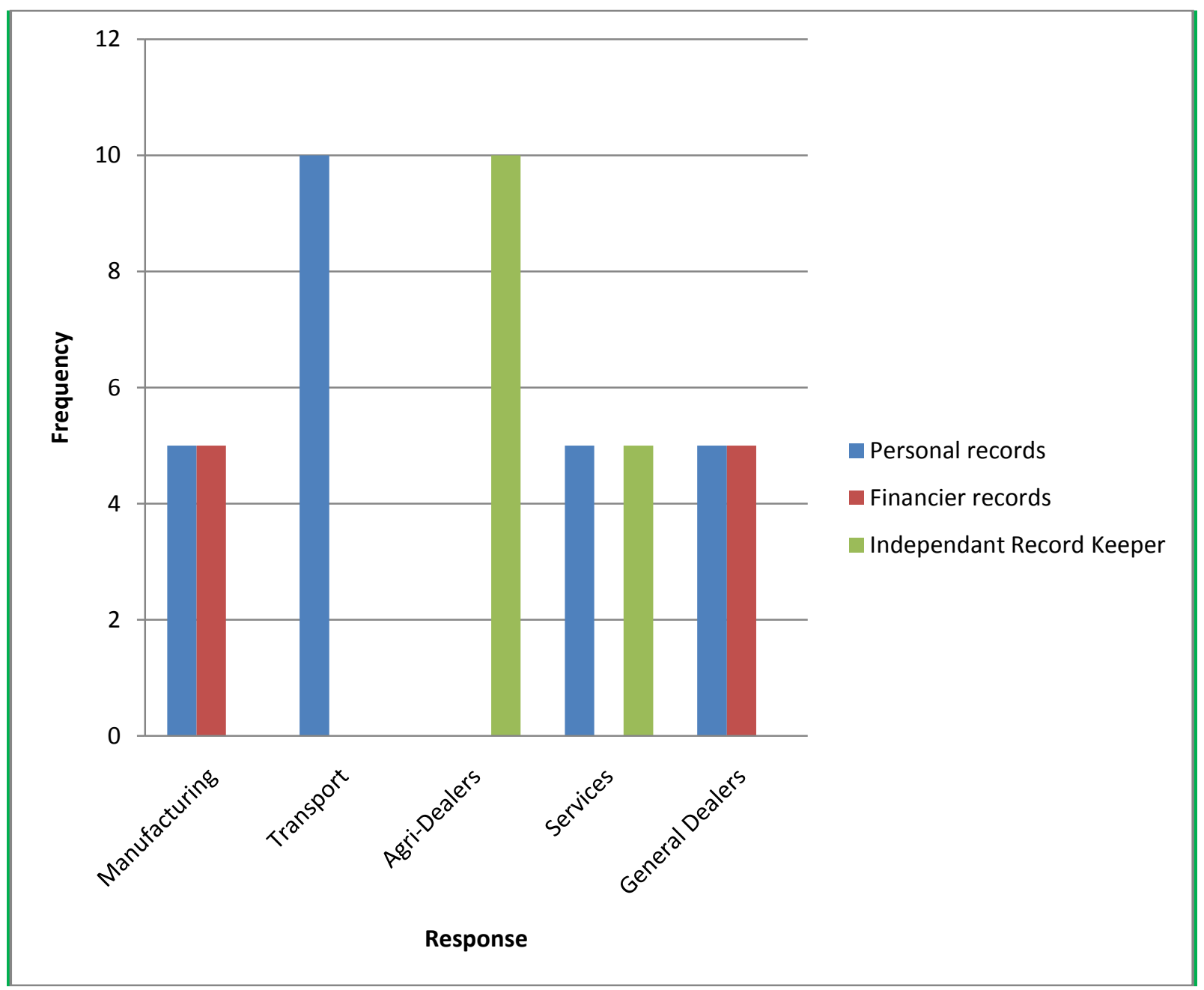

\section{Figure 4.2Use of financial literacy and record keeping}

Fig 4.2 above shows that the manufacturing sector has 5 respondents who indicated that they do not keep personal records while the other 5 indicated that the financier would be likely to be keeping records on their behalf since they do not know how to do it. All the 10 transport operators (taxis) indicated that they do not personally keep records. The Agri-Dealers however indicated that someone else who might be interested in keeping their records have to do it for them. They do no keep any record of their activities at all. Service providers also indicated that they do not keep records while another independent record keeper also keeps records for example ZIMRA or bank through which they would have borrowed finance. The General dealers expressed they do not keep records but also expressed that financiers may keep records on their behalf.

\section{Measurement of Productivity}

It is a public secret that the Zimbabwean rural populace is the largest population compared to mushrooming of urban centres. Thus, obviously, in the current situation where industrial employment rate has hit rock bottom the GDP is measured through the production of the populace of the country which are the rural folks.

Without record keeping and records to go by it, production of rural projects mostly financed at small scale level may be nothing to go by let alone to be measured against contribution to the GDP. There has been attempts to try and measure what these projects are contributing and how. 


\section{Measurement 1: Existential differences amongst rural people}

The living conditions and the lifestyles of those engaged in small rural projects are remarkably different from those who are not. Even in their localities, there are other people better than others because of these projects. A family who has joined an irrigation scheme and who are selling their agricultural produce, for example, are likely to be different because they can afford to buy cattle, a scotch cart, wheel barrows, picks and shovels, tools that a regular family may struggle to acquire.

Some who may be running General Dealers and Service Providers or Shops may show difference by having a well articulate homestead with corrugated roofs or tiled roofs and possesses all other desires that other families may yearn to have. A car to facilitate the business may be an added advantage.

\section{Measurement 2 : Remarkable lifestyle differences}

To those who are financially literate, their lifestyles in rural areas are remarkably different from the rest of other rural folks. They may even manage to have bank accounts, live a better life than city life with Solar Electricity and Borehole Pumps with reticulated water and sometimes a fleet of different cars. They may even have cabled Satellite Dish on their TVs and all the haves that the city people may yearn for. Thus, their businesses if measured formally could be contributing highly to the GDP.

\subsection{Conclusion (s)}

5.1 From the research findings, the researchers concluded that the majority of the rural projects people are not aware of record keeping exercises and they do not want to affect them.

5.2 The researchers also concluded that most people in rural projects use existential differences to show difference in lifestyles.

5.3 The researchers also concluded that most of the people in rural projects believe that they can still do better without financial literacy, so it may be time wasting.

\subsection{Recommendations}

6.1 Based on the research findings and conclusions above, the researchers recommend that there is need for a massive awareness campaign that would change the mind set of most rural projects people so that they do record keeping that would enhance their performance.

6.2 The researchers also recommend that there should be Accounting Extension Services as they do on Agricultural Extension Services. This will help rural projects on their day to day businesses and it will also mean record keeping by the Extension Officers.

6.3 The researchers also recommend that as much as there are Free Legal Services, Accounting Services should be accorded to rural projects at concessional costs so that record keeping exists amongst rural projects in the country at large.

\subsection{References}

1. Amoako G. K. (2013). Accounting Practices of SMES: A Case Study of Kumasi Metropolis in Ghana. Accounting Department Kumasi polytechnic, Ghana.

2. Bradshaw T. M. and Miller, G. S. (2007), Will harmonize Accounting Standards Really Harmonize Accounting? Havard Business School.

3. Bowen, M., Morara, M., Mureithi, S. (2009). Management of business challenges among small and micro enterprises in Nairobi Kenya. KCA Journal of Business Management Vol.2, Issue 1.

4. Butler, A. (2009). Importance of Bookkeeping in Business. Darby: Butler and Company

5. Chiapetta, B. K. show and wild, J.(2009). Principles of Financial Accounting 19th edition, New York: McGraw-Hill Irwin.

6. Cooper, A. C. (1998). Find on Predictors of Performance from Large Scale Research Program, Small Enterprise Research. The Journal of SEAANC, 6 (1) pp 3-9

7. Costae, V. (2011). Determinants of Corporate Financial Performance.

8. Covin, J.G. \& Slevin, D.P. (1989). Strategic Management of Small Firms in Hostile and Benign Environments, Strategic Management Journal, 10:75-87

9. Curley, D. \& Flynn, A.(2005).Is Bank Finance the Achilles' Heel Irish SMEs? Journal of European Industrial Training 29,712-729

10. Daft, R, L. (1995). Organization Theory and Design,(5th edition). Minneapolis, st.paul: MN West Publishing Company. 51 
11. Grant, R. M. (1991). The Resource Based Theory of Competitive Advantage: Implications for Strategy Formulation. California Management Review, 33, 144 - 135.

12. Germain, P, J. (2010). Small Business Bookkeeping.Ezinearticles.com.

13. Kerlinger. F. N (1986). Foundation of Behavioral Research. Washington: Holt Rinehart and Wineton.

14. Longenecker, J. G., Petty, C. W., Moore, J. W. and Palich, L. E. (2006). Small Business Management, An entrepreneurial emphasis. London: Thomson South Western.

15. Locke, E. A. \& Latham, G.P.(1990). What should we do about Motivation Theory? Six Recommendations for the Twenty first Century, Academy of Management Review, 29 (3) 388 - 403

16. Lybaert, N (1998). The Information use in an SME: Its Importance and Some Elements of Influence, Small Business Economics, 10(2), pp 171 - 19153

17. Maseko, N, \& Manyani, O.(2011)Accounting Practices of SMEs in Zimbabwe, Journal of Accounting and Taxation vol. 3 (8) pp $171-181$.

18. Mukaila, A.A. \& Adeyemi, S.L.(2011). Small and Medium Scale Enterprises as a Survival Strategy for Employment Generation in Nigeria, Journal of Sustainable Development Vol. 4 No. 1

19. Olatunji, T.E (2013).The Impact of Accounting System on the Performance of Small and Medium Enterprises in Nigeria, A Survey of SME's in Oyo State - Nigeria, International Journal of Business and Management Invention Vol. 2 (issue 9) pp $13-17$.

20. Peacock, R.W (2000). Find the Causes of Small Business Failure, Management Forum, 11 (2) pp 77-89 